International Journal of Current Advanced Research

ISSN: O: 2319-6475, ISSN: P: 2319 - 6505, Impact Factor: SJIF: 5.995

Available Online at www.journalijcar.org

Volume 6; Issue 3; March 2017; Page No. 2469-2472

DOI: http://dx.doi.org/10.24327/ijcar.2017.2472.0030

\title{
KNOWLEDGE, ATTITUDES AND PRACTICE SURVEY OF RABIES AND ITS PREVENTION IN A RURAL POPULATION OF BARABANKI, UTTAR PRADESH
}

\section{1*Mukesh Shukla and ${ }^{2}$ Siraj Ahmad}

${ }^{1}$ Department of Community Medicine, Hind Institute of Medical Sciences, Sitapur, Uttar Pradesh

${ }^{2}$ Department of Community Medicine, Hind Institute of Medical Sciences, Barabanki, Uttar Pradesh

\section{A R T I C L E I I N F O}

Article History:

Received $18^{\text {th }}$ December, 2016

Received in revised form $16^{\text {th }}$ January, 2017

Accepted $26^{\text {th }}$ February, 2017

Published online $28^{\text {th }}$ March, 2017

\section{Key words:}

Knowledge, Attitude, Practice, Rabies

\begin{abstract}
A B S T R A C T
Background: Rabies, a fatal and neglected zoonotic disease, is reported from each and every part of India. Although rabies has been endemic and causes substantial loss, minimal community based studies have been conducted to understand the epidemiology of rabies.
\end{abstract}

Objectives: The overall objective of this research was to have a better understanding of the epidemiology of rabies focussing on Knowledge, Attitudes and Practices of rabies andits control measures among the rural population.

Material \&Methods: A community based cross-sectional study was conducted among 210 households having 1332individualsin rural population of Barabanki, Uttar Pradesh. A predesigned, pre-tested semi structured questionnaire was used to collect socio-demographic information and to assess knowledge, attitudes andpracticesof rabies andits controlmeasures.

Results: Among all the respondents, there was a high level of awareness (85.2\%) that dog is the most common reservoir of rabies. Majority of the study subjects stated that the disease is fatal $(73.3 \%)$ and that rabies can be prevented by vaccination $(83.3 \%)$. However knowledge of study subjects about proper wound management was suboptimal. Only about $23 \%$ of the subjects had the knowledge regarding proper wound management. Out of the 28 subjects, who themselves or any of their family members, were bitten by dog during last one year, 24 of them sought treatment and got vaccinated when recommended.

Conclusion: The study reveals that the level of awareness regarding rabies and its control measures were satisfactory. However awareness regarding wound management needs to be enhanced through community based intervention and IEC (Information, Education and Communication) activities.

Copyright $\bigcirc 2017$ Mukesh Shukla and Siraj Ahmad. This is an open access article distributed under the Creative Commons Attribution License, which permits unrestricted use, distribution, and reproduction in any medium, provided the original work is properly cited.

\section{INTRODUCTION}

Rabies is a fatal zoonotic disease of worldwide importance with considerable magnitude in India. It is transmitted through rabid animal bite, of which domestic dogs are responsible for majority (99\%) of cases of human deaths due to rabies worldwide. [Knobel 2005] Almost 98\% of the human rabies cases occur in developing countries that possess large number of dogs, many of which are stray. [WHO 2004] About 65,000 people across the globe and 20,000 people in India die of rabies every year, thereby making it the nation with the highest rabies mortality in Asia and the second highest in the world. [APCRI 2011] Control of rabies in the animal reservoirs like domestic dogs is the only means to prevent the transmission cycle of disease and eliminateboth dog and human rabies cases in the world. [Cleaveland 2006 and Zinstag 2007] Currently, rabiesis reported from each and every part of India;

*Corresponding author: Mukesh Shukla Department of Community Medicine, Hind Institute of Medical Sciences, Sitapur, Uttar Pradesh with sporadic occurrences even inthe previously free areas, and domestic dogs are mainlyaccountable for transmission of rabies in livestock as well as humans. There are various fables and false beliefs related to wound management including topical use of various oils with herbs and even application of red chillies on the biteof rabid animals.[Singh 2005] More reliance on traditional native medicinal technique and methodsthat are of unproven efficacy, and not washing the wound properly because of the fear that it would get infected, is quite common in practice. [Sekhon 2002] Poor public knowledge towards rabies is considered as one of the hurdles in prevention and control of this disease.Therefore, understanding the perception of community in terms of epidemiology of rabies is an essential pre-requisite; for coming out withstrategies to bring this problem within grab, and for implementation of the concerned planned activities in the future. Therefore, this study was designed to assess the level of knowledge, attitude and practicesamong people regarding prevention and control of rabies. 


\section{MATERIAL AND METHODS}

Study Design: This is a community based cross-sectional study.

Study Area: This study was conducted in catchment area of Rural Health Training Centre, Satrikh, Hind Institute of Medical Sciences, Barabanki district UP.

Study Period: The study was carried out from January 2017to February 2017.

Study Participants: A maximum of 210 households having 1332 individuals were approached andenrolled during the study time frame, after obtaining verbal consent from them. Multistage sampling technique was applied. In order to recruit the study subjects eight villages were randomly chosen from sixteen villages under RHTC. In selected villages, all the houses were numbered serially. Then the first house was selected randomly and the subsequent houses were selected randomly using table of random numbers.Approximately equal numbers of individuals were included from each of the randomly selected villages.

Study Tool: A pretested and structured questionnaire was prepared to assess the awareness of individualsaboutrabies and knowledge regardingbites by animals, including first aid measures adopted by them as well as awareness regarding anti-rabies vaccines.

Statistical Analysis: Data was entered in Microsoft excel and the major findings were analysedaccording to the aims and objectives by using EPIINFO and findings were presented on the pre- designed classified tables.

\section{RESULTS}

Out of the 210 households, comprising of 1260 individuals, majority of them were nuclear family $(58.5 \%)$. About half of the households consisted of 5-6 members in the family. About three-fourth of the families belonged to Hindu religion. Almost half of them belonged to backward castes. More thantwo-third of the families belonged to upper lower and below socio-economic status. [Table No. 1]

Table no. 1 Distribution of households on the basis of baseline characteristics $(\mathrm{N}=210)$

\begin{tabular}{|c|c|c|}
\hline Households Characteristics & Number & Percentage (\%) \\
\hline \multicolumn{3}{|c|}{ Family type } \\
\hline Nuclear & 123 & 58.5 \\
\hline Joint & 87 & 41.5 \\
\hline \multicolumn{3}{|c|}{ Number of family members } \\
\hline Up to 4 & 73 & 34.7 \\
\hline $5-6$ & 106 & 50.4 \\
\hline$>6$ & 31 & 14.7 \\
\hline \multicolumn{3}{|c|}{ Religion } \\
\hline Hindu & 159 & 75.7 \\
\hline Muslim & 51 & 24.2 \\
\hline \multicolumn{3}{|c|}{ Social class } \\
\hline General & 74 & 35.2 \\
\hline $\begin{array}{l}\text { Other Backward Castes } \\
\text { (OBC) }\end{array}$ & 97 & 46.1 \\
\hline $\mathrm{SC} / \mathrm{ST}$ & 39 & 18.5 \\
\hline \multicolumn{3}{|c|}{ Socio-economic status * } \\
\hline Upper middle and above & 6 & 2.8 \\
\hline Lower Middle & 23 & 10.9 \\
\hline Upper lower & 103 & 49.0 \\
\hline Lower & 78 & 37.1 \\
\hline
\end{tabular}

*Modified UdaiPareekh socioeconomic scale 2015

One adult member of the household preferably head of the family was interviewed regarding knowledge regarding rabies and first aid measures after dog bite. About $85 \%$ of them had knowledge of transmission of rabies through animal bite (most frequent answer was bite by dog). However, none of them knew about any other mode of transmission. Almost two third (73.3) of them knew that rabies is a disease with $100 \%$ fatality rate and stated about the symptoms like aerophobia/hydrophobia during rabies. Almost $80 \%$ of the subjects stated that rabies can be prevented by timely vaccination. In respect to first aid measures after dog bite about $83.8 \%$ believed that proper dressing of the wound is needed, $59.5 \%$ stated about washing of wound with soap and water, while $60.4 \%$ opined regarding cleaning of wound with antiseptic. Also $43.8 \%$ stated that wound should be sutured immediately. [Table No. 2]

Table no.2 Distribution of respondents on the basis of knowledge about rabies and first-aid measures after dog bite $(\mathrm{N}=210)$

\begin{tabular}{|c|c|c|}
\hline \multirow[t]{2}{*}{ Variables } & \multicolumn{2}{|c|}{$\begin{array}{l}\text { Correct answer by the } \\
\text { respondents }\end{array}$} \\
\hline & $\mathbf{n}$ & $(\%)$ \\
\hline \multicolumn{3}{|c|}{ Knowledge regarding Rabies } \\
\hline Mode of transmission through animal bite & 179 & 85.2 \\
\hline $\begin{array}{l}\text { Mode of transmission other than animal } \\
\text { bite, if any }\end{array}$ & 0 & 0 \\
\hline $\begin{array}{c}\text { Symptoms of rabies } \\
\text { (Hydrophobia/Aerophobia) }\end{array}$ & 163 & 77.6 \\
\hline Chances of survival if rabies developed & 154 & 73.3 \\
\hline Can be prevented by vaccination & 175 & 83.3 \\
\hline \multicolumn{3}{|c|}{ Awareness about first aid measures needed after dog bite } \\
\hline Proper dressing of wound & 176 & 83.8 \\
\hline Washing of wound with soap and water & 125 & 59.5 \\
\hline Washing and cleaning with antiseptic & 127 & 60.4 \\
\hline Immediate suturing of wound is important & 92 & 43.8 \\
\hline
\end{tabular}

Out of the total 210 respondents, only 28 subjects were there, who themselves or any of their family members were bitten by dog during last 1 year. Majority of the individuals bitten by dog were children in age -group of $5-15$ years followed by $16-40$ years age group. [Table. 3]

Table No.3 Distribution of the individuals of selected households on basis of age and sex with history of dog bite during last one year $(\mathrm{N}=1332)$

\begin{tabular}{|c|c|c|c|c|}
\hline \multirow{2}{*}{$\begin{array}{c}\text { Age } \\
\text { (In Years) }\end{array}$} & \multicolumn{2}{|c|}{ Males } & \multicolumn{2}{|c|}{ Females } \\
\hline & Total & $\begin{array}{c}\text { History of dog } \\
\text { bite }\end{array}$ & Total & $\begin{array}{c}\text { History of dog } \\
\text { bite }\end{array}$ \\
\hline$<5$ & 35 & $\begin{array}{l}3[8.5 \%] \\
(20.0 \%)\end{array}$ & 38 & $\begin{array}{c}0[0.0] \\
(0.0)\end{array}$ \\
\hline $5-15$ & 204 & $\begin{array}{l}7[3.4 \%] \\
(46.6 \%)\end{array}$ & 197 & $\begin{array}{c}6[3.0] \\
(46.1 \%)\end{array}$ \\
\hline $16-40$ & 328 & $\begin{array}{l}4[1.2 \%] \\
(26.6 \%)\end{array}$ & 223 & $\begin{array}{l}5[2.2 \%] \\
(38.4 \%)\end{array}$ \\
\hline $41-60$ & 131 & $\begin{array}{c}1[0.7 \%] \\
(6.6 \%)\end{array}$ & 136 & $\begin{array}{l}2[1.4 \%] \\
(15.3 \%)\end{array}$ \\
\hline$>60$ & 17 & $\begin{array}{c}0[0.7 \%] \\
(0.0 \%)\end{array}$ & 23 & $\begin{array}{c}0[0.0 \%] \\
(0.0 \%)\end{array}$ \\
\hline Total & 715 & 15 & 617 & 13 \\
\hline
\end{tabular}

[Row \%]; (Column \%)

As the history stated by the respondents, majority of the dog bite injury were of category II $(67.8 \%)$, followed by $25 \%$ cases of category III. 
Table no.4 Distribution of respondents on the basis of health seeking behaviour after dog bite and its category during last one year $(\mathrm{N}=28)$

\begin{tabular}{ccccccccc}
\hline & \multicolumn{6}{c}{ Category of Dog Bite } & \multirow{2}{*}{ Health Services Sought } \\
\cline { 2 - 7 } & \multicolumn{4}{c}{ Cat I } & \multicolumn{3}{c}{ Cat II } & \multicolumn{2}{c}{ Cat III } & Total \\
\cline { 2 - 7 } & $\mathbf{n}$ & $\mathbf{( \% )}$ & $\mathbf{n}$ & $\mathbf{( \% )}$ & $\mathbf{n}$ & $\mathbf{( \% )}$ & \\
\hline $\begin{array}{c}\text { Did Nothing } \\
\text { Visited Medical practioner }\end{array}$ & 1 & 50 & 1 & 5.2 & - & - & 2 \\
$\begin{array}{c}\text { and taken vaccination, if } \\
\text { recommended }\end{array}$ & 1 & 50 & 16 & 84.2 & 7 & 100 & 24 \\
$\begin{array}{c}\text { Visited Quacks/Traditional } \\
\text { Health }\end{array}$ & - & - & 1 & 5.2 & - & - & 1 \\
$\begin{array}{c}\text { Home Based Remedies } \\
\text { Total }\end{array}$ & - & - & 1 & 5.2 & - & - & 1 \\
\hline
\end{tabular}

There was only one case of dog bite of category I. In Majority of the cases proper treatment was sought and vaccination was taken, if prescribed. Only one case of category II dog bite applied home- based remedy and didn 't consult. [Table. 4]

\section{DISCUSSION}

Limited community based Indian studies are present in context to knowledge regarding the rabies in general population focussing specifically the rural areas. In the present study the incidence of dog bite during last one year was about $2.2 \%$. The results are quite comparable with the findings of other Indian studies, where they reported the incidence of about $2.5 \%$ \& $2.0 \%$ in Ballabgarh \& Patna. [Agarwal 2003 and Agarwal 2016] According to the report of WHO, the incidence of animal bite was reported about $1.74 \%$. [10] In line with the other Indian study, the proportion of individuals affected by dog bite was highest in age group of children 5 - 15 years. [Agarwal 2003, Agarwal 2016, Sudarshan 2006, Beck 1985] Neeraj et al; opined that as the children are quite weak in self-protection, that's why they are more prone to such bite incidents. Regarding the knowledge about mode of transmission, like other studies more than $80 \%$ of the respondents were aware that rabies is most likely to result due to animal bite. [Singh 2005 and Tenzin 2012] Apart from as reported by Singh et al; almost all of them knew that it is transmitted by bite of rabid dog. In present study almost all the cases of dog bite visited medical practioner and sought proper treatment. The results are quite comparable to that reported by Neeraj et al., where majority of the cases took treatment from health care services. Also the findings were in line in respect to the preference over home based remedies/quacks/traditional healers. [Agarwal 2016] However the findings are contradictory to that reported by Singh et al., where only $36.4 \%$ of the people opined to visit doctor in case of dog bite. [Sekhon 2002] In our study about $83.8 \%$ of respondents believed that rabies can be prevented by vaccination. In a report of Centre of Disease Control, similar types of findings were observed. [CDC 1981] In a study by Singh et al., in Gujrat $86.6 \%$ people were aware about anti rabies vaccine. [Sekhon 2002] Awareness regarding washing of wound with soap and water was found in only $59.5 \%$ of the respondents which revealed lack of awareness; a finding similar to that reported by Neeraj et al. [Agarwal 2016]

However study has some limitations. As the study was conducted only in rural field practice area, results might not be generalizable. More or less the study had a descriptive approach with a considerable small sample that can be maximally achieved during the time frame of the study therefore temporal relationship couldn't be drawn out. But in spite of that, study finding provide an insight over the current knowledge regarding rabies and animal bite management among general population.

\section{CONCLUSION}

Most of the respondents showed optimal knowledge regarding rabies. However there was a gap in knowledge about first aid measures to be followed after dog bite. Therefore awareness raising campaigns focusing on knowledge about the risk associated with animal bite and need for immediate wound management should be addressed at community level.

\section{References}

1. Knobel, D. L., Cleaveland, S., Coleman, P.G., Fevre, E.M., Meltzer, M.I., Miranda, M.E.G., Shaw, A., Zinsstag, J. \&Meslin, F.X. Re-evaluating the burden of rabies in Africa and Asia. Bulletin of the World Health Organization 2005;83: 360-368.

2. WHO, 2004. First Report of Expert the WHO Consultation on Rabies: Technical Report Series 931. Geneva, Switzerland.[Last accessed on 23 Dec 2016]

3. World Health Organization. Assessing burden of rabies in India. Association for Prevention and Control of Rabies in India (APCRI); 2011. Available from: http://rabies.org.in/rabies/wp-

content/uploads/2011/whosurvey.pdf [Last accessed on 2012 June 16].

4. Cleaveland, S., Kaare, M., Knobel, D. \&Laurenson, M.K. (2006). Canine vaccination- Providing broader benefits for disease control. Veterinary Microbiology 2006; 117: 43-50.

5. Zinsstag, J., Schelling, E., Roth, F., Bonfoh, B., Savigny, D. \& Tanner, M. Human benefits of animal interventions for zoonosis control. Emerging Infectious Disease 2007; 13: 527-531.

6. U. S. Singh, S.K. Choudhary. Knowledge, Attitude, Behaviour and Practice Study on Dog-Bites and Its Management in the Context of Prevention of Rabies in a Rural Community of Gujarat. Indian Journal of Community Medicine 2005;30 (3):81-83.

7. A.S. Sekhon, Amarjit Singh, ParamjitKaur, Sonia Gupta. Misconceptions and Myths in the management of animal bite case. Indian Journal of Community Medicine 2002; 1(1): 9-11.

8. Agarwal N, V.P. Reddaiah. Knowledge, attitude and practice following dog bite: a community-based epidemiological study. Health and Population Perspectives and Issues 2003; 26 (4): 154-161.

9. N Agarwal, CM Singh, Kumar Gulshan, S Singh, S Sinha, K Singh and G K Singh.Epidemiology of Dog Bites in Patna: a Cross Sectional Study. Indian Journal of Community \& Family Medicine 2016; 1(2):1-9.

10. WHO 2008. Human rabies deaths - 2004. Geneva: Department of Food Safety, Zoonoses and Foodborne diseases, World Health Organization; 2008. Available from: www.who.int/rabies/rabies_maps/en/index.html [Last accessed on 3 Feb 2017]

11. Sudarshan MK, Mahendra BJ, Madhusudana SN, Narayana DHA, Rahman A, et al. An epidemiological study of animal bites in India: Results of a WHO sponsored national-multicentric rabies survey. $J$ Commun Dis. 2006; 38:32-39. 
12. Beck AM, Jones BA. Unreported dog bites in children. Public Health Rep. 1985; 100(3):315-21.

13. Tenzin Navneet K. DhandBirDojRaiChangloSangay Tenzin Karma TshetenPemaUgyen Karma Singye Michael P. Ward. Community-based study on knowledge, attitudes and perception of rabies in Gelephu, south-central Bhutan. Int Health 2012;4(3): 210-219. [Cross Reference]

\section{Please cite this article in press as:}

Mukesh Shukla and Siraj Ahmad (2017), 'Knowledge, Attitudes And Practice Survey Of Rabies And Its Prevention In A Rural Population Of Barabanki', Uttar Pradesh', International Journal of Current Advanced Research, 6(3), pp. 2469-2472. 